\title{
Pengembangan Pemodelan Multinomial Logit untuk Menentukan Probabilitas Kepemilikan Sepeda Motor di Kota Kupang
}

\author{
Oktovianus Edvict Semiun* \\ Program Studi Teknik Sipil Fakultas Teknik, Universitas Katolik Widya Mandira, \\ Jl. San Juan No.1, Penfui, Kupang, Nusa Tenggara Timur, Indonesia 85361
}

\begin{abstract}
Abstrak
Penelitian ini bertujuan untuk menentukan faktor-faktor yang berpengaruh signifikan terhadap kepemilikan sepeda motor di kota Kupang dan memprediksi besarnya peluang atau probabilitas suatu rumah tangga untuk memiliki satu, dua, dan lebih dari dua sepeda motor sebagai akibat dari perubahan kondisi karakteristik sosio-ekonomi mikro. Penelitian ini berbasis model multinomial logit (MNL) dengan metode maksimum likelihood. Berdasarkan kalibrasi hasil pemodelan, faktor yang berpengaruh signifikan terhadap kepemilikan sepeda motor di Kota Kupang adalah jumlah anggota keluarga, penghasilan, jumlah anggota keluarga yang bekerja, jumlah anggota keluarga yang sekolah, dan waktu tempuh ke sekolah. Perubahan ekstrim keselurahan faktor kepemilikan sepeda motor (nilai berubah dari 0 ke 0.50) akan meningkatkan probabilitas kepemilikan satu sepeda motor sebesar $43.90 \%$, meningkatkan probabilitas kepemilikan dua sepeda motor sebesar $42.07 \%$ dan menurunkan probabilitas kepemilikan lebih dari dua sepeda motor sebesar $85.98 \%$ sebagai akibat dari kecenderungan untuk memiliki mobil pribadi. Pengembangan model ini telah memberikan indikasi pada tren yang diharapkan dari kepemilikan sepeda motor.
\end{abstract}

Kata kunci: karakteristik rumah tangga; kepemilikan sepeda motor; multinomial logit; probabilitas

\begin{abstract}
[Title: Development of Multinomial Logit Modeling to Determine the Probability of Motorcycle Ownership in Kupang City] This study aimed at determining the factors that significantly influenced motorcycle ownership in Kupang city and predicting the magnitude of the probability of a household to own one, two, and more than two motorcycles as a result of changes in condition of micro socio-economic characteristics. This study was based on a multinomial logit model (MNL) with the maximum likelihood method. Based on the calibration of the modeling results, the factors that significantly influenced motorcycle ownership in Kupang city were number of family members, income, number of working family members, number of family members who go to school, and travel time to school. The extreme change in overall motorcycle ownership factors (value changes from 0 to 0.50 ) would increase the probability of ownership of one motorcycle by $43.90 \%$, would increase the probability of ownership of two motorcycles by $42.07 \%$ and would reduce the probability of ownership of more than two motorcycles by $85.98 \%$ as a result of the tendency to own cars. The implementation of this model has provided an indication of the expected trends in motorcycle ownership.
\end{abstract}

Keywords: household characteristics; motorcycle ownership; multinomial logit; probability

\section{Pendahuluan \\ Pertumbuhan ekonomi suatu negara berkembang sangat berkaitan dengan pertumbuhan sektor transportasi. Dalam beberapa tahun terakhir,}

\footnotetext{
${ }^{*)}$ Penulis Korespondensi.

E-mail: oktovianusedvict@gmail.com
}

pertumbuhan ekonomi telah memfasilitasi urbanisasi yang cepat di sebagian besar negara berkembang diikuti oleh peningkatan kepemilikan dan penggunaan kendaraan pribadi secara eksponensial (Sanko $d k k$., 2014). Goodwin dalam Sanko $d k k$. (2014), kendaraan pribadi adalah simbol kekuasaan, status, kontrol, dan kebebasan. Jika pengguna menganggap mobil atau 


\section{TEKNIK, 40 (3), 2019, 185}

motor sebagai kebutuhan, maka akan sulit untuk mengurangi tingkat kepemilikannya.

Tingkat kepemilikan kendaraan didorong oleh peningkatan permintaan perjalanan, peningkatan tingkat pendapatan dan sikap individu terhadap alternatif layanan transportasi umum yang kurang optimal. Hal ini pada gilirannya, telah meningkatkan permintaan akan infrastruktur dan layanan transportasi dan dalam banyak kasus semakin intensif dampak negatif eksternalitas transportasi yang ditimbulkan seperti polusi udara, konsumsi energi tinggi dan hilangnya nyawa akibat kecelakaan (Dargay $d k k$., 2007). Indikasi ini menyoroti pentingnya suatu model permintaan perjalanan yang kuat yang dapat digunakan untuk menginformasikan dan memandu keputusan kebijakan yang diarahkan pada perencanaan, pengendalian dan manajemen pelayanan transportasi dan infrastruktur berkelanjutan.

Kepemilikan sepeda motor tentunya tidak terlepas dari kondisi karakteristik suatu rumah tangga dalam mendukung aktivitas perjalanan dan sangat penting dalam studi pilihan moda saat ini dan di masa depan. Studi tentang sepeda motor diperlukan untuk mengidentifikasi solusi dan regulasi mengenai sepeda motor. Faktor-faktor yang mempengaruhi kepemilikan kendaraan bermotor termasuk kepemilikan mobil dan motor yang berbeda di setiap wilayah perkotaan sangat berkaitan dengan sistem lalulintas dan total pendapatan suatu rumah tangga.

Secara teori, belum ada standar untuk menentukan kepemilikan kendaraan bermotor. Namun, karena referensi yang terbatas tentang subjek ini, beberapa faktor penting yang mempengaruhi kepemilikan sepeda motor dipertimbangkan dari studistudi sebelumnya.

Ada beberapa penelitian yang telah dilakukan sehubungan dengan kepemilikan sepeda motor. Di Kota Penang Malaysia, diteliti oleh Leong dan Sadullah (2007). Penelitiannya menggunakan model multinomial logit untuk menguji kepemilikan sepeda motor. Mereka menegaskan bahwa total penghasilan rumah tangga bulanan, kepemilikan mobil, kepemilikan SIM dan jumlah anggota rumah tangga mempengaruhi kepemilikan sepeda motor. Studi ini menyimpulkan bahwa sepeda motor akan tetap menjadi moda transportasi, khususnya pada kelompok rumah tangga berpendapatan rendah dan menengah. Bila jumlah anggota keluarga bertambah, kemungkinan untuk memiliki sepeda motor berkurang dan lebih cenderung untuk membeli mobil.

Di Thailand, Prabnasak $d k k$. (2011) menunjukkan bahwa penghasilan rumah tangga dan kepemilikan sepeda motor cenderung meningkat sampai mencapai level tertentu. Saat penghasilan meningkat sampai level tertentu, tingkat kepemilikan sepeda motor akan cenderung berkurang dan tingkat kepemilikan mobil pada akhirnya akan melampaui sepeda motor. Studi ini mengidentifikasi bahwa peenghasilan berpengaruh signifikan terhadap kepemilikan kendaraan rumah tangga dimana sepeda motor sangat popular diantara rumah tangga yang berpenghasilan rendah dan menengah sementara mobil pribadi lebih diminati oleh rumah tangga yang berpenghasilan tinggi.

Di Akure, ibukota negara bagian Ondo di Nigeria Barat Daya, Oyedepo \& Etu (2015) meneliti faktor rumah tangga yang mempengaruhi kepemilikan sepeda motor. Kepemilikan sepeda motor dipelajari pada tingkat rumah tangga menggunakan survei kuisioner rumah tangga dan model regresi logistik binomial untuk menganalisis data. Analisis dilakukan untuk menentukan pengaruh berbagai faktor terhadap keputusan rumah tangga untuk memiliki atau tidak memiliki sepeda motor. Pengaruh faktor-faktor ini menandakan bahwa rumah tangga lebih mungkin memiliki sepeda motor dengan penghasilan bulanan rata-rata yang lebih rendah, kualifikasi akademik yang lebih rendah, dan jumlah anggota rumah tangga yang lebih tinggi.

Di Indonesia, Wedagama (2013) dan Massara $d k k$. (2018) juga meneliti tentang kepemilikan sepeda motor. Wedagama (2013) melakukan penelitian tentang pengaruh penghasilan rumah tangga terhadap kepemilikan sepeda motor di Kabupaten Buleleng. Analisis menggunakan model multinomial logit. Hasil yang diperoleh menegaskan bahwa probabilitas kepemilikan sepeda motor meningkat secara substansial jika penghasilan rumah tangga di Kabupaten Buleleng meningkat. Sedangkan Massara $d k k$. (2018) menegaskan bahwa kepemilikan kendaraan di kota Makassar dapat dipengaruhi oleh beberapa faktor. Salah satu faktornya adalah faktor sosial ekonomi yang terkait dengan perilaku masyarakat baik sebagai pengguna jalan maupun bukan pengguna jalan. Faktor sosial ekonomi yang dapat mempengaruhi kepemilikan sepeda motor adalah jumlah anggota keluarga dan jarak perjalanan total semua anggota keluarga.

Studi-studi yang diulas telah mampu menilai dan mengidentifikasi faktor-faktor yang mempengaruhi kepemilikan sepeda motor di berbagai kota di beberapa negara berkembang. Namun, Kupang sebagai kota urbanisasi yang ada di Indonesia memiliki kekhasan tersendiri dalam hal faktor-faktor yang mempengaruhi karakteristik kepemilikan sepeda motor.

Jumlah penduduk kota Kupang sampai pada akhir tahun 2017 sebesar 412,708 jiwa dengan laju pertumbuhan penduduk pertahun $2.97 \%$ dari tahun 2010 (Badan Pusat Statistik Kota Kupang, 2018), menambah permasalahan transportasi di kota Kupang. Tingkat penggunaan angkutan umum cenderung menurun sehingga belum bisa dijadikan solusi penyelesaian masalah kepadatan lalulintas. Kinerja operasi yang belum optimal, manajemen pengoperasian angkutan 


\section{TEKNIK, 40 (3), 2019, 186}

umum yang kurang baik serta kebijakan transportasi yang kurang kondusif terhadap kinerja operasional angkutan umum di kota Kupang diyakini menyebabkan jumlah penumpang angkutan umum mulai berkurang (Semiun, 2018).

Di sisi lain, jumlah kepemilikan kendaraan pribadi meningkat secara signifikan terutama sepeda motor. Jumlah sepeda motor di kota Kupang meningkat 259\% dari 47,586 pada tahun 2009 menjadi 171,129 pada tahun 2017 (Badan Pusat Statistik Kota Kupang, 2018). Penggunaan moda pribadi khususnya sepeda motor yang secara individu relatif fleksibel, semakin popular dan semakin diminati masyarakat sehinga menjadi masalah kritis untuk keselamatan dan pengelolaan sistem lalulintas di kota Kupang. Selain sebagai moda yang memudahkan suatu individu dalam melakukan aktivitas perjalanannya, sepeda motor juga dimanfaatkan sebagai alat transportasi umum (ojek), alat perjudian (balap liar) bahkan yang lebih buruk dimanfaatkan sebagai sarana untuk melakukan tindak kejahatan. Hal ini tentunya membuat masalah transportasi di Kota Kupang menjadi lebih kompleks. Oleh karena itu, dalam penelitian ini, masalah mengenai kepemilikan sepeda motor akan diselidiki.

Penelitian ini bertujuan untuk menentukan faktorfaktor yang mempengaruhi kepemilikan sepeda motor di kota Kupang berdasarkan karakteristik rumah tangga penduduk dan berupaya untuk mengembangkan model prediksi yang dapat digunakan untuk memperkirakan besarnya peluang atau probabilitas suatu rumah tangga untuk memiliki sepeda motor sebagai akibat dari perubahan kondisi karakteristik sosio-ekonomi mikro.

\section{Metode Penelitian}

Model regresi logistik multinomial merupakan perpanjangan dari regresi logistik biner (Aldrich \& Nelson, 1984; Hosmer \& Lemeshow, 2000) dan sangat efektif jika variabel dependen merupakan data kategori polikotom. Dalam sebuah model MNL, estimasi parameter dapat diidentifikasi dan dibandingkan dengan kategori dasar dari variabel dependen (Long, 1997).

Tujuan dari model Multinomial Logit (MNL) adalah memperkirakan fungsi yang menentukan hasil probabilitas. Penelitian ini menggunakan model MNL untuk menyelidiki hubungan antara faktor-faktor karakteristik suatu rumah tangga dan kepemilikan sepeda motor (satu, dua dan lebih dari dua sepeda motor) di Kota Kupang, Nusa Tenggara Timur. Satu kategori kepemilikan dipilih sebagai kategori referensi, biasanya nilai dengan frekuensi terendah atau tertinggi.

Dalam penelitian ini, model MNL didasarkan pada konsep ekonomi mikro dari maksimisasi utilitas sehingga simulasi yang dilakukan mengandaikan bahwa suatu rumah tangga lebih memilih untuk memiliki sejumlah sepeda motor dengan dasar bahwa ia menyediakan utilitas paling banyak dalam arti ekonomi. Model ini digunakan untuk memperkirakan utilitas yang disediakan oleh masing-masing kategori kepemilikan di wilayah studi menggunakan Persamaan 1.

$$
\mathrm{U}_{\mathrm{SM}}=\alpha_{\mathrm{SM}}+\alpha_{1} \mathrm{Z}_{1}+\alpha_{2} \mathrm{Z}_{2}+\ldots+\alpha_{\mathrm{n}} \mathrm{Z}_{\mathrm{n}}
$$

Dimana $\mathrm{U}_{\mathrm{SM}}$ adalah utilitas yang disediakan oleh kategori kepemilikan SM, $\alpha_{S M}$ adalah konstanta, $\alpha_{1}-\alpha_{n}$ adalah koefisien model yang ditentukan oleh model dan $\mathrm{Z}_{1}-\mathrm{Z}_{\mathrm{n}}$ adalah parameter kategori.

Dengan utilitas yang dihitung menggunakan Persamaan 1, probabilitas suatu rumah tangga yang memiliki sejumlah sepeda motor (satu, dua dan lebih besar dari dua sepeda motor) dihitung menggunakan Persamaan 2 dan 3.

$$
\begin{aligned}
\mathrm{P}_{\mathrm{SM}} & =\frac{\exp \left(\alpha_{\mathrm{SM}}+\alpha_{1} \mathrm{Z}_{1}+\ldots+\alpha_{n} \mathrm{Z}_{n}\right)}{\sum\left(\exp \left(\alpha_{\mathrm{SM}}+\alpha_{1} \mathrm{Z}_{1}+\ldots+\alpha_{\mathrm{n}} \mathrm{Z}_{\mathrm{n}}\right)\right)} \\
P_{S M} & =\frac{\exp \left(\mathrm{U}_{\mathrm{SM}}\right)}{\sum\left(\exp \left(\mathrm{U}_{\mathrm{SM}}\right)\right.}
\end{aligned}
$$

Dimana $\mathrm{P}_{\mathrm{SM}}$ adalah probabilitas suatu rumah tangga memiliki sepeda motor berjumlah SM dan merupakan penjumlahan utilitas indeks dari berbagai kategori. Probabilitas kepemilikan sepeda motor utntuk kategori referensi dibatasi antara nol dan satu. Untuk penelitian ini, kategori kepemilikan 1 sepeda motor dipilih sebagai kategori referensi.

Survey kuisioner rumah tangga dilakukan untuk memperoleh data primer berupa variabel-variabel karakteristik rumah tangga (sosio-ekonomi) yang mempengaruhi kepemilikan sepeda motor.

Kuisioner disebarkan secara acak (stratified random sampling) kepada responden sebanyak 326 rumah tangga berdasarkan perhitungan ukuran populasi dan sampel dengan rumus Slovin. Populasi dalam penelitian ini adalah jumlah kepala keluarga di kota Kupang sebanyak 97725 rumah tangga (BPS Kota Kupang, 2018). Dengan jumlah sampel dan populasi tersebut, ambang kesalahannya (margin of error) adalah 5.43 persen (pers. 4).

$\mathrm{n}_{0}=\frac{\mathrm{Z}^{2} p q}{e^{2}}$

Dimana: $\mathrm{e}=$ ambang kesalahan, $\mathrm{p}=$ probabilitas jawaban benar $(0,5), \mathrm{n}=$ jumlah sampel $(326), \mathrm{q}=1-\mathrm{p}$, $\mathrm{Z}=95$ persen (nilai tabel dari selang kepercayaan 95 persen $=1,96)$.

Penyebaran kuisioner dilakukan pada enam wilayah kecamatan yang ada di kota Kupang dengan 


\section{TEKNIK, 40 (3), 2019, 187}

jumlah sampel masing-masing kecamatan dapat dilihat pada Tabel 1. Pengumpulan dan analisis data dilakukan selama dua bulan yaitu dari bulan Februari sampai bulan Maret tahun 2019.

Tabel 1. Jumlah Sampel setiap Kecamatan

\begin{tabular}{lcc}
\hline \multicolumn{1}{c}{ Kecamatan } & Jumlah Sampel & Proporsi Sampel \\
\hline Alak & $48 \mathrm{KK}$ & $14.72 \%$ \\
Maulafa & $124 \mathrm{KK}$ & $38.04 \%$ \\
Oebobo & $57 \mathrm{KK}$ & $17.48 \%$ \\
Kota Raja & $36 \mathrm{KK}$ & $11.04 \%$ \\
Kelapa Lima & $41 \mathrm{KK}$ & $12.58 \%$ \\
Kota Lama & $20 \mathrm{KK}$ & $6.13 \%$ \\
\hline \multicolumn{1}{c}{ Total } & $\mathbf{3 2 6}$ KK & $\mathbf{1 0 0 . 0 0 \%}$ \\
\hline
\end{tabular}

Model kepemilikan sepeda motor dalam penelitian ini merupakan model kalibrasi MNL menggunakan bantuan Software SPSS 16. Variabel dependen dan independen merupakan data kategori yang ditampilkan dalam Tabel 2. Sebelum dilakukan kalibrasi pemodelan, terlebih dahulu dilakukan pengujian validitas dan reliabilitas data kuisioner agar data yang digunakan valid dan akurat. Setelah model MNL kepemilikan sepeda motor dinyatakan valid dan akurat maka akan dilakukan interpretasi terhadap probabilitas yang terjadi berbasis nilai Odds dan simulasi peluang.

Tabel 2. Variabel penelitian

\begin{tabular}{|c|c|c|c|}
\hline \multicolumn{2}{|c|}{ Variabel } & \multirow[t]{2}{*}{ Symbol } & \multirow[t]{2}{*}{ Coding } \\
\hline \multicolumn{2}{|l|}{ Variabel dependen } & & \\
\hline Kepemilikan Sepeda & 1 Sepeda Motor & $1 \mathrm{SM}$ & 1 \\
\hline Motor & 2 Sepeda Motor & $2 \mathrm{SM}$ & 2 \\
\hline & $>2$ Sepeda Motor & $>2 \mathrm{SM}$ & 3 \\
\hline \multicolumn{4}{|l|}{ Variabel Independen } \\
\hline Jumlah Anggota & 1-2 orang & JAK1 & 1 \\
\hline Keluarga & 3 orang atau lebih & JAK2 & 2 \\
\hline \multirow[t]{3}{*}{ Penghasilan } & $<2 \mathrm{jt}$ & Peng1 & 1 \\
\hline & $2-4 \mathrm{jt}$ & Peng2 & 2 \\
\hline & $>4 \mathrm{jt}$ & Peng3 & 3 \\
\hline \multirow[t]{2}{*}{ Jenis Pekerjaan } & PNS/BUMN & JP1 & 1 \\
\hline & Non PNS/BUMN & JP2 & 2 \\
\hline Jumlah Anggota & 1 orang & JAKB 1 & 1 \\
\hline Keluarga yang & 2 orang atau lebih & $\mathrm{JAKB} 2$ & 2 \\
\hline \multicolumn{4}{|l|}{ Bekerja } \\
\hline Jumlah Anggota & 1 orang & JAKS1 & 1 \\
\hline Keluarga yang & 2 orang atau lebih & JAKS2 & 2 \\
\hline \multicolumn{4}{|l|}{ Sekolah/Kuliah } \\
\hline Jarak Tempuh ke & $<10 \mathrm{~km}$ & DistB1 & 1 \\
\hline \multirow[t]{2}{*}{ Tempat Kerja } & $10-20 \mathrm{~km}$ & DistB2 & 2 \\
\hline & $>20 \mathrm{~km}$ & DistB3 & 3 \\
\hline Jarak Tempuh ke & $<10 \mathrm{~km}$ & DistS1 & 1 \\
\hline \multirow[t]{2}{*}{ Sekolah } & $10-20 \mathrm{~km}$ & DistS2 & 2 \\
\hline & $>20 \mathrm{~km}$ & DistS3 & 3 \\
\hline Waktu Tempuh ke & $<15$ menit & TimeB1 & 1 \\
\hline \multirow[t]{2}{*}{ Tempat Bekerja } & 15-30 menit & TimeB2 & 2 \\
\hline & $>30$ menit & TimeB3 & 3 \\
\hline Waktu Tempuh ke & $<15$ menit & TimeS1 & 1 \\
\hline \multirow[t]{2}{*}{ Sekolah } & 15-30 menit & TimeS1 & 2 \\
\hline & $>30$ menit & TimeS1 & 3 \\
\hline
\end{tabular}

\section{Hasil dan Pembahasan \\ 3.1 Karakteristik Responden di Kota Kupang}

Secara umum, proporsi karakteristik responden hasil penyebaran kuisioner untuk kepemilikan sepeda motor di Kota Kupang ditampilkan dalam Tabel 3.

Tabel 3. Karakteristik Responden

\begin{tabular}{|c|c|c|c|}
\hline \multicolumn{4}{|c|}{ Case Processing Summary } \\
\hline & & $N$ & $\begin{array}{c}\text { Marginal } \\
\text { Percentage }\end{array}$ \\
\hline Kepemilikan Sepeda & 1 Sepeda Motor & 94 & $28.8 \%$ \\
\hline \multirow{2}{*}{ Motor } & 2 Sepeda Motor & 146 & $44.8 \%$ \\
\hline & $>2$ Sepeda Motor & 86 & $26.4 \%$ \\
\hline Jumlah Anggota & $1-2$ orang & 156 & $47.9 \%$ \\
\hline Keluarga & 3 orang atau lebih & 170 & $52.1 \%$ \\
\hline \multirow[t]{3}{*}{ Penghasilan } & $<2 \mathrm{jt}$ & 68 & $20.9 \%$ \\
\hline & $2-4 \mathrm{jt}$ & 147 & $45.1 \%$ \\
\hline & $>4 \mathrm{jt}$ & 111 & $34.0 \%$ \\
\hline \multirow[t]{2}{*}{ Jenis Pekerjaan } & PNS/BUMN & 165 & $50.6 \%$ \\
\hline & Non PNS/BUMN & 161 & $49.4 \%$ \\
\hline Jumlah Anggota & 1 orang & 114 & $35.0 \%$ \\
\hline Keluarga yang & 2 orang atau lebih & 212 & $65.0 \%$ \\
\hline \multicolumn{4}{|l|}{ Bekerja } \\
\hline Jumlah Anggota & 1 orang & 45 & $13.8 \%$ \\
\hline Keluarga yang & 2 orang atau lebih & 281 & $86.2 \%$ \\
\hline \multicolumn{4}{|l|}{ Sekolah/Kuliah } \\
\hline Jarak Tempuh ke & $<10 \mathrm{~km}$ & 111 & $34.0 \%$ \\
\hline \multirow[t]{2}{*}{ Tempat Kerja } & $10-20 \mathrm{~km}$ & 142 & $43.6 \%$ \\
\hline & $>20 \mathrm{~km}$ & 73 & $22.4 \%$ \\
\hline Jarak Tempuh ke & $<10 \mathrm{~km}$ & 96 & $29.4 \%$ \\
\hline \multirow[t]{2}{*}{ Sekolah } & $10-20 \mathrm{~km}$ & 186 & $57.1 \%$ \\
\hline & $>20 \mathrm{~km}$ & 44 & $13.5 \%$ \\
\hline Waktu Tempuh ke & $<15$ menit & 95 & $29.1 \%$ \\
\hline \multirow[t]{2}{*}{ Tempat Bekerja } & 15-30 menit & 177 & $54.3 \%$ \\
\hline & $>30$ menit & 54 & $16.6 \%$ \\
\hline Waktu Tempuh ke & $<15$ menit & 91 & $27.9 \%$ \\
\hline \multirow[t]{2}{*}{ Sekolah } & 15-30 menit & 191 & $58.6 \%$ \\
\hline & $>30$ menit & 44 & $13.5 \%$ \\
\hline Valid & & 326 & $100.0 \%$ \\
\hline Missing & & 0 & \\
\hline Total & & 326 & \\
\hline
\end{tabular}

3.2 Uji Validitas, Reliabilitas dan Multikolinearitas

Sebelum dilakukan pemodelan, terlebih dahulu dilakukan uji validitas dan reliabilitas data kuisioner agar data yang digunakan sudah valid dan akurat. Pengujian validitas menggunakan korelasi Person Product Moment dengan kriteria validitas $\mathrm{r}$ hitung lebih besar dari $\mathrm{r}$ tabel pada derajat signifikan 5\% dan taraf $\mathrm{df}$ (degree of freedom) $\mathrm{n}-2=324$.

Pada Tabel 4 dengan $\mathrm{df}=324$ diperoleh nilai $r$ table 0.109 sehingga variabel independen dalam kuisioner yang tidak valid dan harus dikeluarkan dari model adalah jenis pekerjaan, jarak tempuh ke tempat kerja dan jarak tempuh ke sekolah.

Uji reliabilias dilakukan setelah uji validitas pada variabel independen dinyatakan valid. Uji reliabilitas menggunakan metode Cronbach's Alpha. Jika alpha > 0.90 maka reliabilitas sempurna. Jika alpha antara $0.70-$ 0.90 maka reliabilitas tinggi. Jika alpha $0.50-0.70$ maka reliabilitas moderat. Jika alpha $<0.50$ maka 


\section{TEKNIK, 40 (3), 2019, 188}

reliabilitas rendah. Jika alpha rendah, berarti item tidak reliabel. Berdasarkan Tabel 5, nilai Cronbach's Alpha menunjukan nilai diatas 0.50 sehingga variabel independen dinyatakan reliable.

Tabel 4. Hasil uji validitas kuisioner

\begin{tabular}{|c|c|c|}
\hline & & $\begin{array}{c}\text { Kepemilikan } \\
\text { Sepeda } \\
\text { Motor }\end{array}$ \\
\hline Kepemilikan Sepeda & Pearson Correlation & 1 \\
\hline \multirow[t]{2}{*}{ Motor } & Sig. (2-tailed) & \\
\hline & $N$ & 326 \\
\hline Jumlah Anggota & Pearson Correlation & $.564^{* *}$ \\
\hline \multirow[t]{2}{*}{ Keluarga } & Sig. $(2$-tailed $)$ & .000 \\
\hline & $N$ & 326 \\
\hline \multirow[t]{3}{*}{ Penghasilan } & Pearson Correlation & $.533^{* *}$ \\
\hline & Sig. $(2$-tailed $)$ & .000 \\
\hline & $N$ & 326 \\
\hline \multirow[t]{3}{*}{ Jenis Pekerjaan } & Pearson Correlation & .008 \\
\hline & Sig. (2-tailed) & .888 \\
\hline & $N$ & 326 \\
\hline Jumlah Anggota & Pearson Correlation & $.426^{* *}$ \\
\hline \multirow[t]{2}{*}{ Keluarga yang Bekerja } & Sig. $(2$-tailed $)$ & .000 \\
\hline & $N$ & 326 \\
\hline Jumlah Anggota & Pearson Correlation & $.298^{* *}$ \\
\hline Keluarga yang & Sig. $(2$-tailed $)$ & .000 \\
\hline Sekolah/Kuliah & $N$ & 326 \\
\hline Jarak Tempuh ke & Pearson Correlation & .062 \\
\hline \multirow{2}{*}{ Tempat Kerja } & Sig. (2-tailed) & .267 \\
\hline & $N$ & 326 \\
\hline Jarak Tempuh ke & Pearson Correlation & .076 \\
\hline \multirow[t]{2}{*}{ Sekolah } & Sig. $(2$-tailed $)$ & .170 \\
\hline & $N$ & 326 \\
\hline Waktu Tempuh ke & Pearson Correlation & $.218^{* *}$ \\
\hline \multirow[t]{2}{*}{ Tempat Bekerja } & Sig. (2-tailed $)$ & .000 \\
\hline & $N$ & 326 \\
\hline Waktu Tempuh ke & Pearson Correlation & $.427^{* *}$ \\
\hline \multirow[t]{2}{*}{ Sekolah } & Sig. (2-tailed) & .000 \\
\hline & $N$ & 326 \\
\hline
\end{tabular}

Tabel 5. Hasil Uji Reliabilitas Kuisioner

\begin{tabular}{lccc}
\hline \multicolumn{1}{c}{ Variabel } & $\begin{array}{c}\text { Cronbach's } \\
\text { Alpha }\end{array}$ & Syarat & Ket. \\
\hline Jumlah Anggota Keluarga & 0.663 & 0.500 & $\begin{array}{l}\text { Reliable } \\
\text { Reliable }\end{array}$ \\
$\begin{array}{l}\text { Penghasilan } \\
\text { Jumlah Anggota Keluarga }\end{array}$ & 0.660 & 0.500 & Reliable \\
$\begin{array}{l}\text { yang Bekerja } \\
\text { Jumlah Anggota Keluarga }\end{array}$ & 0.700 & 0.500 & Reliable \\
$\begin{array}{l}\text { yang Sekolah/Kuliah } \\
\text { Waktu Tempuh ke Tempat }\end{array}$ & 0.712 & 0.500 & Reliable \\
$\begin{array}{l}\text { Bekerja } \\
\text { Waktu Tempuh ke Sekolah }\end{array}$ & 0.692 & 0.500 & Reliable \\
\hline
\end{tabular}

Tahap selanjutnya adalah melakukan pengujian multikolinearitas agar model yang dihasilkan tidak bias dan memiliki kekuatan prediksi yang handal dan stabil. Tabel 6 menunjukkan hasil uji multikolinearitas. Nilai Tolerance untuk semua variabel independen mendekati 1 dan nilai VIF kurang dari 10 sehingga diduga tidak terjadi multikolinearitas sehingga dapat dilanjutkan untuk dilakukan pemodelan.
Tabel 6. Hasil Uji Multikolinearitas

\begin{tabular}{llcc}
\hline \multicolumn{1}{c}{ Model } & \multicolumn{2}{c}{ Collinearity } & Statistics \\
& & Tolerance & VIF \\
\hline $1 \quad$ (Constant) & 0.839 & 1.192 \\
& Jumlah Anggota Keluarga & 0.785 & 1.273 \\
& Penghasilan & 0.831 & 1.204 \\
& & \\
& Jumlah Anggota Keluarga yang & 0.924 & 1.082 \\
& Bekerja & \\
& Jumlah Anggota Keluarga yang & & \\
& Sekolah/Kuliah & 0.900 & 1.111 \\
& Waktu Tempuh ke Tempat Bekerja & 0.908 & 1.102 \\
$\quad$ Waktu Tempuh ke Sekolah & \\
\hline a. Dependent Variable: Kepemilikan Sepeda Motor &
\end{tabular}

\subsection{Informasi Pemasangan Model}

Efektifitas keseluruhan model MNL dinilai dengan menggunakan statistik Chi-square. Nilai Chisquare 340.258 dan nilai $\alpha=0.000$ kurang dari 0.05 (lihat Tabel 7). Hal ini menunjukkan hubungan yang signifikan antara variabel dependen dan himpunan variabel independen pada akhir model.

Tabel 7. Informasi pemasangan model

\begin{tabular}{lcccc}
\hline Model & $\begin{array}{c}\text { Model Fitting } \\
\text { Criteria }\end{array}$ & \multicolumn{2}{c}{ Likelihood Ratio Tests } \\
& $\mathbf{- 2}$ Log Likelihood & Chi- & Sf & Sig. \\
\hline Intercept Only & 524.804 & & & \\
Final & 184.546 & 340.258 & 18 & 0.000 \\
\hline
\end{tabular}

Nilai statistik Chi-square tidak dapat menunjukkan kekuatan hubungan antara variabel dependen/respon dan variabel independen/predictor. Untuk itu dalam model MNL digunakan Pseudo $R$ Square dan akurasi klasifikasi model untuk mengukur kekuatan hubungan antar variabel seperti yang ditunjukkan pada Tabel 8, Tabel 9 dan Tabel 10.

Tabel 8 menunjukkan bahwa ketiga langkah tersebut (nilai Cox and Snell, Nagelkerke dan McFadden) mengindikasikan korelasi yang cukup kuat antara variabel dependen dan himpunan variabel independen. Indikasi ini didukung dengan keakuratan klasifikasi model yang dinilai dan disajikan pada Tabel 9 dan Tabel 10.

Tingkat akurasi klasifikasi dalam pemodelan MNL biasanya digunakan 25 persen atau lebih, dimana harus lebih besar dari tingkat akurasi proporsional sampel variabel dependen. Tingkat akurasi proporsional data merupakan hasil penjumlahan kuadrat dari persentase jumlah sampel setiap kategori variabel dependen. Dalam penelitian ini digunakan tingkat akurasi klasifikasi sebesar $100 \%$ atau dua kali lebih tinggi dari tingkat akurasi data sehingga diperoleh kriteria akurasi untuk model MNL kepemilikan sepeda motor adalah $70.67 \%$ (lihat Tabel 9).

Model MNL secara umum memperkirakan $74.2 \%$ dengan benar pada keseluruhan kategori 


\section{TEKNIK, 40 (3), 2019, 189}

kepemilikan sepeda motor. Secara individual, kategori 1 sepeda motor diprediksi 91.5\% dengan benar, kategori 2 sepeda motor diprediksi $82.9 \%$ dengan benar dan kategori lebih dari 2 sepeda motor diprediksi $40.7 \%$ dengan benar.

Berdasarkan Tabel 10, tingkat akurasi klasifikasi keseluruhan adalah $74.2 \%$ yang lebih besar dari kriteria akurasi $70.67 \%$. Oleh karena itu, kriteria ketepatan klasifikasi untuk model MNL dalam penelitian ini tergolong akurat.

Tabel 8. Pseudo R-Square

\begin{tabular}{cc}
\hline Cox and Snell & 0.648 \\
Nagelkerke & 0.734 \\
McFadden & 0.488 \\
\hline
\end{tabular}

Tabel 9. Kiteria Akurasi Model MNL

\begin{tabular}{cccc}
\hline $\begin{array}{c}\text { Kepemilikan Sepeda } \\
\text { Motor }\end{array}$ & $\boldsymbol{N}$ & $\begin{array}{c}\text { Marginal } \\
\text { Percentage }\end{array}$ & $\begin{array}{c}\text { Marginal } \\
\text { Percentage } \\
\text { Square }\end{array}$ \\
\hline 1 Sepeda Motor & 94 & $28.8 \%$ & 0.082944 \\
2 Sepeda Motor & 146 & $44.8 \%$ & 0.200704 \\
> 2 Sepeda Motor & 86 & $26.4 \%$ & 0.069696 \\
Tingkat akurasi proporsional data & 0.353344 \\
Tingkat akurasi klasifikasi (> 25\%) & $100 \%$ \\
\multicolumn{3}{c}{ Kriteria akurasi } & 0.706688 \\
\hline
\end{tabular}

Tabel 10. Klasifikasi Akurasi Model MNL

\begin{tabular}{ccccc}
\hline & \multicolumn{4}{c}{ Predicted } \\
\cline { 2 - 5 } Observed & $\begin{array}{c}\text { 1 Sepeda } \\
\text { Motor }\end{array}$ & $\begin{array}{c}\text { 2 Sepeda } \\
\text { Motor }\end{array}$ & $\begin{array}{c}>\mathbf{2} \\
\text { Sepeda } \\
\text { Motor }\end{array}$ & $\begin{array}{c}\text { Percent } \\
\text { Correct }\end{array}$ \\
\hline $\begin{array}{c}\text { 1 Sepeda } \\
\text { Motor }\end{array}$ & 86 & 8 & 0 & $91.5 \%$ \\
$\begin{array}{c}\text { 2 Sepeda } \\
\text { Motor }\end{array}$ & 15 & 121 & 10 & $82.9 \%$ \\
$>$ 2 Sepeda \\
$\begin{array}{c}\text { Motor } \\
\text { Overall }\end{array}$ & 4 & 47 & 35 & $40.7 \%$ \\
Percentage & $32.2 \%$ & $54.0 \%$ & $13.8 \%$ & $74.2 \%$ \\
\hline
\end{tabular}

\subsection{Pengembangan Model Multinomial Logit (MNL)}

Penelitian ini menggunakan Model Multinomial

Logit (MNL) untuk memprediksi seberapa besar probabilitas suatu rumah tangga memiliki sepeda motor di kota Kupang. Metode maximum likelihood digunakan untuk menghitung koefisien parameter model. Dua persamaan multinomial logit akan diperoleh dimana kepemilikan 1 sepeda motor dalam rumah tangga dijadikan sebagai kategori referensi/kategori dasar.

Model MNL yang pertama membandingkan probabilitas kepemilikan 2 sepeda motor terhadap kepemilikan 1 sepeda motor mencakup keseluruhan variabel independen (jumlah anggota keluarga, penghasilan, jumlah anggota keluarga yang bekerja, jumlah anggota keluarga yang sekolah/kuliah, waktu tempuh ke tempat kerja dan waktu tempuh ke sekolah). Model MNL yang kedua membandingkan probabilitas kepemilikan lebih dari 2 sepeda motor terhadap kepemilikan 1 sepeda motor mencakup keseluruhan variabel independen yang sama.

Estimasi parameter dalam model MNL berfungsi untuk mengukur probabilitas perubahan logit untuk perubahan satu unit variabel independen dimana variabel independen yang lain adalah konstan. Dalam penelitan ini, koefisien variabel independen yang bernilai positif mengartikan adanya peluang peningkatan kepemilikan 2 sepeda motor dan kepemilikan lebih dari 2 sepeda motor. Sedangkan jika koefisien variabel independen bernilai negatif berarti peluang atau probabilitas kepemilikan 2 sepeda motor dan kepemilikan lebih dari 2 sepeda motor cenderung menurun atau dengan kata lain terjadi peningkatan peluang untuk kepemilikan 1 sepeda motor.

Nilai signifikansi (Sig.) pada variabel independen untuk model MNL mengindikasikan apakah ada peluang terjadinya perubahan secara signifikan yang mengubah logit pada tingkat kepercayaan yang diterima. Jika nilai Sig. lebih besar dari tingkat kepercayaan yang diterima maka disimpulkan tidak cukup bukti bahwa perubahan variabel independen mempengaruhi kategori respons variabel dependen terhadap kategori referensi/dasar. Dalam penelitian ini digunakan tingkat kepercayaan sebesar 95\% atau nilai Sig. 0.05 .

Tabel 11 menunjukkan multikolinearitas tidak ada dalam model karena tidak ada nilai standard error (Std. Error) dari koefisien $\beta$ yang memiliki nilai lebih dari 1.96 (Washington $d k k$., 2003).

Tabel 11 menjelaskan bahwa jumlah anggota keluarga kategori 1-2 orang $(\mathrm{JAK}=1)$ berpengaruh signifikan negatif dengan kepemilikan 2 sepeda motor dan lebih dari 2 sepeda motor sehingga cenderung memiliki peluang $87.6 \%$ (1-0.124) dan $98.1 \%$ (1-0.019) relatif lebih kecil untuk memiliki 2 sepeda motor dan lebih dari 2 sepeda motor terhadap 1 sepeda motor daripada kategori 3 orang atau lebih $(\mathrm{JAK}=2)$. Atau dengan kata lain, kategori 1-2 orang $(\mathrm{JAK}=1)$ cenderung memiliki peluang lebih besar 8.08 kali $(\operatorname{Exp}(2.089))$ untuk memiliki 1 sepeda motor terhadap 2 sepeda motor dan memiliki peluang lebih besar 52.83 kali $(\operatorname{Exp}(3.967))$ untuk memiliki 1 sepeda motor terhadap lebih dari 2 sepeda motor daripada kategori 3 orang atau lebih $(\mathrm{JAK}=2)$.

Kategori penghasilan yang lebih kecil dari dua juta rupiah (Peng=1) dan penghasilan dua sampai empat juta rupiah $(\mathrm{Peng}=2)$ berpengaruh signifikan negatif dengan kepemilikan 2 sepeda motor dan lebih dari 2 sepeda motor sehingga cenderung memiliki peluang 99.6\% (1-0.004) dan 94.8\% (1-0.052) relatif lebih kecil untuk memiliki 2 sepeda motor terhadap 1 sepeda motor dan cenderung memiliki peluang 99.4\% (1-0.006) dan 96.6\% (1-0.034) lebih kecil untuk memiliki lebih dari 2 sepeda motor terhadap 1 sepeda motor daripada kategori penghasilan yang lebih besar dari empat juta rupiah 


\section{TEKNIK, 40 (3), 2019, 190}

(Peng=3) dalam suatu rumah tangga. Atau dengan kata lain, penghasilan yang lebih kecil dari dua juta rupiah (Peng=1) dan dua sampai empat juta rupiah (Peng=2) cenderung memiliki peluang lebih besar 240.33 kali $(\operatorname{Exp}(5.482)) \quad$ dan 19.09 kali $(\operatorname{Exp}(2.949))$ untuk memiliki 1 sepeda motor terhadap 2 sepeda motor daripada penghasilan diatas empat juta rupiah (Peng=3).
Sedangkan terhadap kepemilikan lebih dari 2 sepeda motor, penghasilan yang lebih kecil dari dua juta rupiah (Peng=1) dan dua sampai empat juta rupiah (Peng=2) cenderung memiliki peluang lebih besar 177.51 kali $(\operatorname{Exp}(5.179)) \quad$ dan 29.67 kali $(\operatorname{Exp}(3.390))$ untuk memiliki 1 sepeda motor daripada penghasilan diatas empat juta rupiah (Peng=3).

Tabel 11. Estimasi parameter - kepemilikan 2 sepeda motor dan lebih dari 2 sepeda motor versus 1 sepeda motor

\begin{tabular}{|c|c|c|c|c|c|c|c|c|c|}
\hline \multirow{2}{*}{\multicolumn{2}{|c|}{ Kepemilikan Sepeda Motor ${ }^{a}$}} & \multirow{3}{*}{$\begin{array}{c}\boldsymbol{B} \\
7.704\end{array}$} & \multirow{3}{*}{$\begin{array}{r}\text { Std. Error } \\
1.797\end{array}$} & \multirow{3}{*}{$\begin{array}{c}\text { Wald } \\
18.379\end{array}$} & \multirow{3}{*}{$\begin{array}{r}D f \\
1\end{array}$} & \multirow{3}{*}{$\begin{array}{l}\text { Sig. } \\
.000\end{array}$} & \multirow{3}{*}{$\operatorname{Exp}(B)$} & \multicolumn{2}{|c|}{ 95\% CI for $\operatorname{Exp}(B)$} \\
\hline & & & & & & & & \multirow[t]{2}{*}{ Lower Bound } & \multirow[t]{2}{*}{ Upper Bound } \\
\hline 2 Sepeda Motor & Intercept & & & & & & & & \\
\hline & {$[\mathrm{JAK}=1]$} & -2.089 & .542 & 14.870 & 1 & .000 & .124 & .043 & .358 \\
\hline & {$[\mathrm{JAK}=2]$} & $0^{\mathrm{b}}$ & & . & 0 & & & & . \\
\hline & {$[$ Peng=1] } & -5.482 & 1.156 & 22.500 & 1 & .000 & .004 & .000 & .040 \\
\hline & [Peng=2] & -2.949 & 1.094 & 7.263 & 1 & .007 & .052 & .006 & .447 \\
\hline & [Peng=3] & $0^{\mathrm{b}}$ & & . & 0 & & . & . & . \\
\hline & {$[\mathrm{JAKB}=1]$} & -2.329 & .496 & 22.086 & 1 & .000 & .097 & .037 & .257 \\
\hline & {$[\mathrm{JAKB}=2]$} & $0^{\mathrm{b}}$ & & & 0 & & . & & . \\
\hline & {$[\mathrm{JAKS}=1]$} & -2.142 & .640 & 11.216 & 1 & .001 & .117 & .034 & .411 \\
\hline & {$[\mathrm{JAKS}=2]$} & $0^{\mathrm{b}}$ & . & . & 0 & . & . & . & . \\
\hline & {$[$ TimeB $=1]$} & -.370 & .724 & .261 & 1 & .609 & .691 & .167 & 2.854 \\
\hline & {$[$ TimeB $=2]$} & .020 & .670 & .001 & 1 & .976 & 1.021 & .274 & 3.798 \\
\hline & {$[$ TimeB=3] } & $0^{\mathrm{b}}$ & & & 0 & & . & . & . \\
\hline & [TimeS=1] & -1.528 & 1.291 & 1.400 & 1 & .237 & .217 & .017 & 2.726 \\
\hline & {$[\mathrm{TimeS}=2]$} & -.729 & 1.252 & .339 & 1 & .560 & .483 & .042 & 5.610 \\
\hline & {$[\mathrm{TimeS}=3]$} & $0^{\mathrm{b}}$ & & . & 0 & & . & . & . \\
\hline \multirow[t]{16}{*}{ > 2 Sepeda Motor } & Intercept & 9.694 & 1.842 & 27.699 & 1 & .000 & & & \\
\hline & {$[\mathrm{JAK}=1]$} & -3.967 & .658 & 36.372 & 1 & .000 & .019 & .005 & .069 \\
\hline & {$[\mathrm{JAK}=2]$} & $0^{\mathrm{b}}$ & & . & 0 & & . & - & . \\
\hline & {$[$ Peng=1] } & -5.179 & 1.289 & 16.153 & 1 & .000 & .006 & .000 & .070 \\
\hline & [Peng=2] & -3.390 & 1.136 & 8.906 & 1 & .003 & .034 & .004 & .312 \\
\hline & [Peng=3] & $0^{\mathrm{b}}$ & & & 0 & & & & . \\
\hline & {$[\mathrm{JAKB}=1]$} & -2.208 & .612 & 13.020 & 1 & .000 & .110 & .033 & .365 \\
\hline & {$[\mathrm{JAKB}=2]$} & $0^{\mathrm{b}}$ & . & . & 0 & . & . & . & . \\
\hline & {$[\mathrm{JAKS}=1]$} & -2.142 & .843 & 6.453 & 1 & .011 & .117 & .023 & .613 \\
\hline & {$[\mathrm{JAKS}=2]$} & $0^{\mathrm{b}}$ & & . & 0 & & . & . & . \\
\hline & {$[$ TimeB=1] } & .159 & .867 & .034 & 1 & .854 & 1.173 & .214 & 6.418 \\
\hline & {$[$ TimeB $=2]$} & .664 & .787 & .713 & 1 & .399 & 1.943 & .416 & 9.079 \\
\hline & {$[$ TimeB $=3$ ] } & $0^{\mathrm{b}}$ & & & 0 & & 然 & . & . \\
\hline & {$[$ TimeS=1] } & -5.285 & 1.338 & 15.609 & 1 & .000 & .005 & .000 & .070 \\
\hline & {$[$ TimeS=2] } & -3.404 & 1.257 & 7.338 & 1 & .007 & .033 & .003 & .390 \\
\hline & {$[$ TimeS=3] } & $0^{\mathrm{b}}$ & & - & 0 & & . & . & . \\
\hline
\end{tabular}

a. The reference category is: 1 Sepeda Motor.

b. This parameter is set to zero because it is redundant.

Jumlah anggota keluarga yang bekerja untuk kategori 1 orang $(\mathrm{JAKB}=1)$ berpengaruh signifikan negatif dengan kepemilikan 2 sepeda motor dan lebih dari 2 sepeda motor sehingga cenderung memiliki peluang $90.3 \%(1-0.097)$ dan $89.0 \%(1-0.110)$ relatif lebih kecil untuk memiliki 2 sepeda motor dan lebih dari 2 sepeda motor terhadap 1 sepeda motor daripada kategori 2 orang atau lebih $(\mathrm{JAKB}=2)$. Atau dengan kata lain, kategori 1 orang $(\mathrm{JAKB}=1)$ cenderung memiliki peluang lebih besar 10.27 kali $(\operatorname{Exp}(2.329))$ untuk memiliki 1 sepeda motor terhadap 2 sepeda motor dan memiliki peluang lebih besar 9.10 kali $(\operatorname{Exp}(2.208))$ untuk memiliki 1 sepeda motor terhadap lebih dari 2 sepeda motor daripada kategori 2 orang atau lebih (JAKB=2).

Jumlah anggota keluarga yang sekolah/kuliah untuk kategori 1 orang $(\mathrm{JAKS}=1)$ berpengaruh signifikan negatif dengan kepemilikan 2 sepeda motor dan lebih dari 2 sepeda motor sehingga cenderung keduanya memiliki peluang $88.3 \%(1-0.117)$ relatif 


\section{TEKNIK, 40 (3), 2019, 191}

lebih kecil untuk memiliki 2 sepeda motor dan lebih dari 2 sepeda motor terhadap 1 sepeda motor daripada kategori 2 orang atau lebih $(\mathrm{JAKS}=2)$. Atau dengan kata lain, kategori 1 orang $(\mathrm{JAKS}=1)$ cenderung memiliki peluang lebih besar 8.52 kali $(\operatorname{Exp}(2.142))$ untuk memiliki 1 sepeda motor terhadap 2 sepeda motor dan lebih dari 2 sepeda motor daripada kategori 2 orang atau lebih $(\mathrm{JAKS}=2)$.

Waktu tempuh ke sekolah/kuliah untuk kategori lebih kecil dari 15 menit (TimeS=1) dan 15 sampai 30 menit (TimeS=2) berpengaruh signifikan negatif dengan kepemilikan lebih dari 2 sepeda motor sehingga cenderung memiliki peluang $99.5 \%$ (1-0.005) dan $96.7 \%$ (1-0.033) relatif lebih kecil untuk memiliki lebih dari 2 sepeda motor terhadap 1 sepeda motor daripada kategori lebih besar dari 30 menit (TimeS=3). Atau dengan kata lain, kategori lebih kecil dari 15 menit $(\mathrm{TimeS}=1)$ dan 15 sampai 30 menit $(\mathrm{TimeS}=2$ ) cenderung memiliki peluang lebih besar 197.35 kali $(\operatorname{Exp}(5.285))$ dan 30.08 kali $(\operatorname{Exp}(3.404))$ untuk memiliki 1 sepeda motor terhadap lebih dari 2 sepeda motor daripada kategori yang lebih besar dari 30 menit (TimeS=3).

Untuk menganalisis probabilitas kepemilikan sepeda motor, persamaan logit peluang untuk kepemilikan 2 sepeda motor dan lebih dari 2 sepeda motor dihitung dengan mengalikan koefisien Beta dari tabel estimasi parameter dengan variabel independen (lihat Tabel 11).

Berdasarkan Tabel 11, pada kategori kepemilikan 2 sepeda motor diperoleh hasil bahwa untuk variabel $($ TimeB=1), $\quad($ TimeB=2), $\quad($ TimeS=1) dan $\quad($ TimeS=2) memiliki nilai signifikansi lebih besar dari 0.05 sehingga variabel tersebut tidak masuk dalam model (lihat pers. 6). Hal yang sama juga terlihat pada kategori kepemilikan lebih dari 2 sepeda motor yakni untuk variabel $($ Time $B=1)$ dan $($ Time $B=2)$ memiliki nilai signifikansi lebih besar dari 0.05 sehingga variabel tersebut juga tidak masuk dalam model (lihat pers. 7). Sedangkan untuk variabel $\quad(\mathrm{JAK}=2), \quad(\mathrm{Peng}=3)$, $(\mathrm{JAKB}=2), \quad(\mathrm{JAKS}=2), \quad(\mathrm{TimeB}=3) \quad$ dan $\quad(\mathrm{TimeS}=3)$ merupakan basis kategori referensi untuk masingmasing variabel independen sehingga otomatis tidak masuk dalam model persamaan logit.

Model persamaan logit kepemilikan sepeda motor di kota Kupang pada tingkat kepercayaan 95\% ditunjukkan oleh Persamaan 5 hingga 7.

$$
\begin{aligned}
\log \left(\mathrm{P}_{1 \mathrm{SM}} / \mathrm{P}_{1 \mathrm{SM}}\right)= & \\
\log \left(\mathrm{P}_{2 \mathrm{SM}} / \mathrm{P}_{1 \mathrm{SM}}\right)= & 7.704-2.089\left(\mathrm{JAK}_{1}\right)- \\
& 5.482\left(\mathrm{Peng}_{1}\right)-2.949(\mathrm{Peng} 2)- \\
& 2.329\left(\mathrm{JAKB}_{1}\right)-2.142\left(\mathrm{JAKS}_{1}\right) \\
\log \left(\mathrm{P}_{>2} \mathrm{SM} / \mathrm{P}_{1 \mathrm{SM}}\right)= & 9.694-3.967\left(\mathrm{JAK}_{1}\right)- \\
& 5.179\left(\mathrm{Peng}_{1}\right)-3.390\left(\mathrm{Peng}_{2}\right)- \\
& 2.208\left(\mathrm{JAKB}_{1}\right)-2.142\left(\mathrm{JAKS}_{1}\right)-
\end{aligned}
$$

doi: 10.14710/teknik.v40n3.23072

Copyright (C) 2019, TEKNIK, p-ISSN: 0852-1697, e-ISSN: 240-9919

$$
\text { 5.285 }\left(\mathrm{TimeS}_{1}\right)-3.404\left(\mathrm{TimeS}_{2}\right)
$$

Sehingga diperoleh persamaan model probabilitas MNL kepemilikan sepeda motor adalah berupa Persamaan 8 hingga 10.

$$
\begin{gathered}
P_{(1 S M)}=\frac{e^{\log \frac{P(1 S M)}{P(1 S M)}}}{e^{\log \frac{P(1 S M)}{P(1 S M)}}+e^{\log \frac{P(2 S M)}{P(1 S M)}}+e^{\log \frac{P(>2 S M)}{P(1 S M)}}} \\
P_{(2 S M)}=\frac{e^{\log \frac{P(2 S M)}{P(1 S M)}}}{e^{\log \frac{P(1 S M)}{P(1 S M)}}+e^{\log \frac{P(2 S M)}{P(1 S M)}}+e^{\log \frac{P(>2 S M)}{P(1 S M)}}} \\
P_{(>2 S M)}=\frac{e^{\log \frac{P(>2 S M)}{P(1 S M)}}}{e^{\log \frac{P(1 S M)}{P(1 S M)}}+e^{\log \frac{P(2 S M)}{P(1 S M)}}+e^{\log \frac{P(>2 S M)}{P(1 S M)}}}
\end{gathered}
$$

Selanjutnya dilakukan interpretasi berbasis peluang yang dilakukan dengan cara mensubstitusikan persamaan fungsi logit kepemilikan sepeda motor (5), (6) dan (7) ke dalam persamaan model MNL (8), (9) dan (10). Kemudian dibuat simulasi probabilitas dari semua faktor yang berpengaruh nyata terhadap kepemilikan sepeda motor. Simulasi dilakukan dengan cara meningkatkan nilai faktor tersebut dari nilai minimum $(0 \%)$ ke nilai maksimum (50\%) kemudian dilihat kecendrungan hasil probabilitas suatu rumah tangga untuk memiliki 1 sepeda motor, 2 sepeda motor dan lebih dari 2 sepeda motor. Simulasi dilakukan dalam 4 kategori yang bertujuan untuk melihat sensitivitas kepemilikan sepeda motor yaitu : (1) pada simulasi 1 terjadi peningkatan hanya pada variabel $(\mathrm{JAK}=1)$; (2) pada simulasi 2 terjadi peningkatan hanya pada variabel (Peng=1) dan (Peng=2); (3) pada simulasi 3 terjadi peningkatan hanya pada variabel $(\mathrm{JAKB}=1),(\mathrm{JAKS}=1)$, (TimeS=1) dan (TimeS=2); dan (4) pada simulasi 4 terjadi peningkatan pada keseluruhan variabel yang berpengaruh signifikan.

Tabel 12 dan Gambar 1 menjelaskan bahwa jika terjadi peningkatan pada jumlah anggota keluarga (nilai berubah dari 0 ke 0.50) maka akan meningkatkan probabilitas kepemilikan 1 sepeda motor sebesar $0.03 \%$ (dari $0.01 \%$ menjadi $0.03 \%$ ), meningkatkan probabilitas kepemilikan 2 sepeda motor sebesar $13.87 \%$ (dari $12.03 \%$ menjadi $25.89 \%$ ) dan menurunkan probabilitas kepemilikan lebih dari 2 sepeda motor sebesar $13.90 \%$ (dari $87.97 \%$ menjadi $74.07 \%$ ).

Tabel 13 dan Gambar 2 menjelaskan bahwa jika terjadi peningkatan pada penghasilan (nilai berubah dari

\footnotetext{
doi: $10.14710 /$ eknik.v40n3.23072
} 


\section{TEKNIK, 40 (3), 2019, 192}

0 ke 0.50) maka akan meningkatkan probabilitas kepemilikan 1 sepeda motor sebesar $0.38 \%$ (dari $0.01 \%$ menjadi $0.39 \%$ ), meningkatkan probabilitas kepemilikan 2 sepeda motor sebesar $0.70 \%$ (dari $12.03 \%$ menjadi $12.73 \%$ ) dan menurunkan probabilitas kepemilikan lebih dari 2 sepeda motor sebesar $1.08 \%$ (dari $87.97 \%$ menjadi $86.89 \%$ ).

Tabel 14 dan Gambar 3 menjelaskan bahwa jika terjadi peningkatan pada jumlah anggota keluarga yang bekerja, jumlah anggota keluarga yang sekolah dan waktu tempuh ke Sekolah/Kuliah (nilai berubah dari 0 ke 0.50) maka akan meningkatkan probabilitas kepemilikan 1 sepeda motor sebesar $0.38 \%$ (dari $0.01 \%$ menjadi $0.38 \%$ ), meningkatkan probabilitas kepemilikan 2 sepeda motor sebesar $78.47 \%$ (dari $12.03 \%$ menjadi $90.49 \%$ ) dan menurunkan probabilitas kepemilikan lebih dari 2 sepeda motor sebesar $78.84 \%$ (dari $87.97 \%$ menjadi $9.13 \%$ ).

Tabel 12. Simulasi 1 : probabilitas akibat peningkatan pada variabel jumlah anggota keluarga

\begin{tabular}{cccc}
\hline $\begin{array}{c}\text { Perubahan } \\
\text { Logit }\end{array}$ & P(1 SM) & P(2 SM $)$ & P(>2 SM $)$ \\
\hline 0 & 0.00005 & 0.12025 & 0.87970 \\
0.1 & 0.00008 & 0.14157 & 0.85835 \\
0.2 & 0.00011 & 0.16596 & 0.83393 \\
0.3 & 0.00016 & 0.19360 & 0.80624 \\
0.4 & 0.00023 & 0.22459 & 0.77517 \\
0.5 & 0.00033 & 0.25895 & 0.74072 \\
Selisih & 0.00028 & 0.13870 & -0.13897 \\
\hline
\end{tabular}

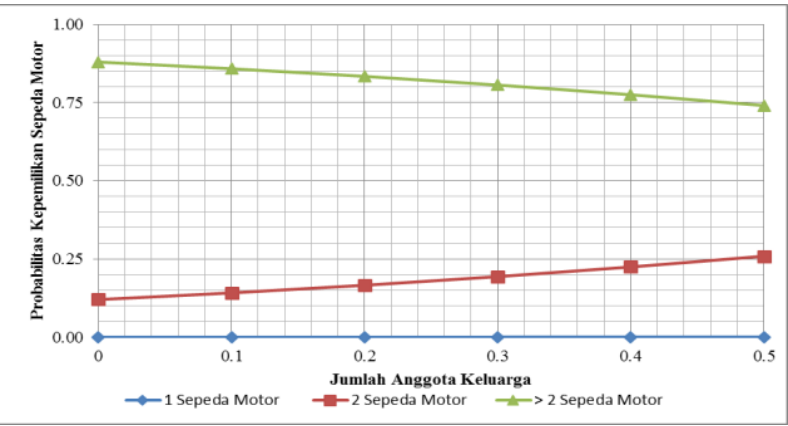

Gambar 1. Probabilitas kepemilikan sepeda motor akibat peningkatan jumlah anggota keluarga

Tabel 13. Simulasi 2 : probabilitas akibat peningkatan pada variabel penghasilan

\begin{tabular}{cccc}
\hline $\begin{array}{c}\text { Perubahan } \\
\text { Logit }\end{array}$ & P(1 SM) & P(2 SM $)$ & P(>2 SM $)$ \\
\hline 0 & 0.00005 & 0.12025 & 0.87970 \\
0.1 & 0.00013 & 0.12171 & 0.87816 \\
0.2 & 0.00030 & 0.12317 & 0.87653 \\
0.3 & 0.00071 & 0.12462 & 0.87468 \\
0.4 & 0.00166 & 0.12601 & 0.87233 \\
0.5 & 0.00389 & 0.12725 & 0.86886 \\
Selisih & 0.00383 & 0.00700 & -0.01084 \\
\hline
\end{tabular}

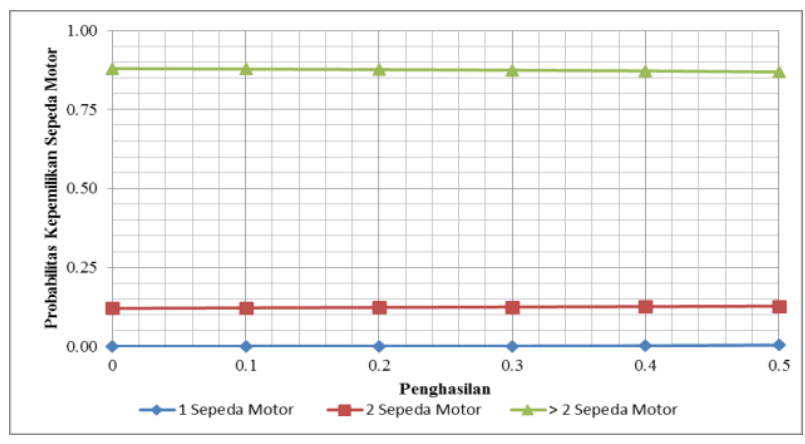

Gambar 2. Probabilitas Kepemilikan Sepeda Motor akibat Peningkatan Penghasilan

Tabel 14. Simulasi 3 : probabilitas akibat peningkatan pada variabel jumlah anggota keluarga yang bekerja, jumlah anggota keluarga yang sekolah dan waktu tempuh ke sekolah

\begin{tabular}{cccc}
\hline $\begin{array}{c}\text { Perubahan } \\
\text { Logit }\end{array}$ & P(1 SM $)$ & P(2 SM $)$ & P(>2 SM $)$ \\
\hline 0 & 0.00005 & 0.12025 & 0.87970 \\
0.1 & 0.00017 & 0.24353 & 0.75630 \\
0.2 & 0.00048 & 0.43113 & 0.56839 \\
0.3 & 0.00110 & 0.64045 & 0.35844 \\
0.4 & 0.00217 & 0.80626 & 0.19156 \\
0.5 & 0.00382 & 0.90491 & 0.09127 \\
Selisih & 0.00376 & 0.78466 & -0.78842 \\
\hline
\end{tabular}

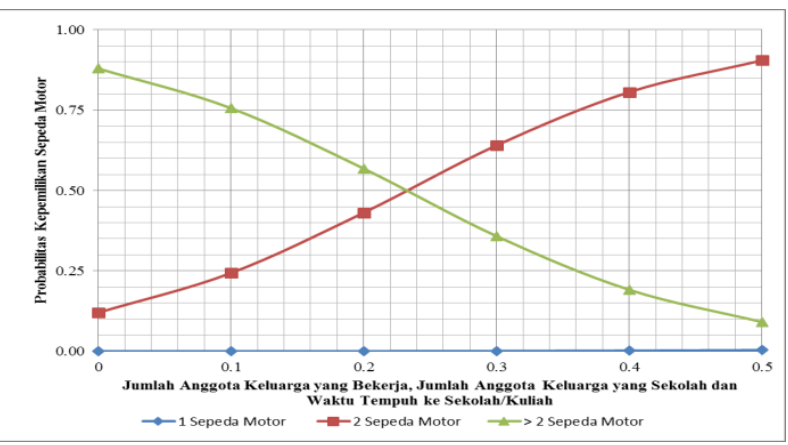

Gambar 3. Probabilitas kepemilikan sepeda motor akibat peningkatan jumlah anggota keluarga yang bekerja, jumlah anggota keluarga yang sekolah dan waktu tempuh ke sekolah

Tabel 15. Simulasi 4 : Probabilitas akibat Peningkatan pada Keseluruhan Variabel Independen yang Berpengaruh Signifikan

\begin{tabular}{cccc}
\hline $\begin{array}{c}\text { Perubahan } \\
\text { Logit }\end{array}$ & P(1 SM) & P(2 SM $)$ & P(>2 SM $)$ \\
\hline 0 & 0.00005 & 0.12025 & 0.87970 \\
0.1 & 0.00057 & 0.28244 & 0.71699 \\
0.2 & 0.00478 & 0.52911 & 0.46610 \\
0.3 & 0.03008 & 0.74285 & 0.22708 \\
0.4 & 0.14083 & 0.77677 & 0.08240 \\
0.5 & 0.43914 & 0.54095 & 0.01991 \\
Selisih & 0.43909 & 0.42070 & -0.85978 \\
\hline
\end{tabular}




\section{TEKNIK, 40 (3), 2019, 193}

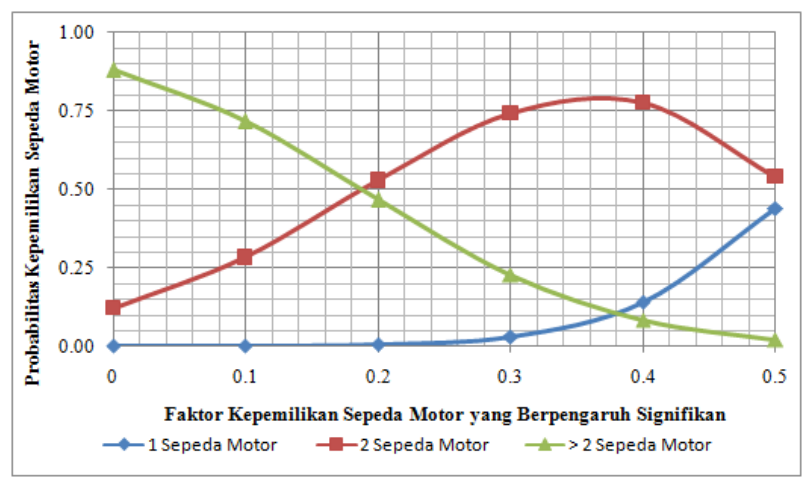

Gambar 4. Probabilitas Kepemilikan Sepeda Motor

Berdasarkan Tabel 15 dan Gambar 4, jika keselurahan faktor kepemilikan sepeda motor bergerak dari nilai minimum ke maksimum maka probabilitas untuk memiliki 1 sepeda motor cenderung meningkat mulai dari $0.01 \%$ menjadi $43.91 \%$. Untuk kepemilikan 2 sepeda motor, probabilitasnya cenderung meningkat dari $12.03 \%$ menjadi $77.68 \%$ kemudian turun menjadi $54.09 \%$. Sedangkan untuk kepemilikan lebih dari 2 sepeda motor, peningkatan keselurahan faktor yang berpengaruh terhadap kepemilikan sepeda motor cenderung menurunkan probabilitasnya yaitu mulai dari $87.97 \%$ menjadi $1.99 \%$. Selain itu, hal lain yang perlu ditekankan adalah peningkatan probabilitas kepemilikan 2 sepeda motor hanya sampai pada nilai $40 \%$ dari peningkatan keseluruhauuuuun variabel yang signifikan. Saat keseluruhan variabel yang berpengaruh signifikan meningkat menjadi $50 \%$, probabilitasnya cenderung menurun karena lebih memilih untuk memiliki kendaraan mobil pribadi.

Perubahan ekstrim keselurahan faktor kepemilikan sepeda motor (nilai berubah dari 0 ke 0.50) akan meningkatkan probabilitas kepemilikan 1 sepeda motor sebesar $43.90 \%$ (dari $0.01 \%$ menjadi $43.91 \%$ ), meningkatkan probabilitas kepemilikan 2 sepeda motor sebesar $42.07 \%$ (dari $12.03 \%$ menjadi $54.09 \%$ ) dan menurunkan probabilitas kepemilikan lebih dari 2 sepeda motor sebesar $85.98 \%$ (dari $87.97 \%$ menjadi $1.99 \%)$.

Penelitian ini relevan dengan hasil penelitan yang dilakukan oleh Gbagir $d k k$. (2018) yang menyimpulkan bahwa pada kondisi ekonomi yang menguntungkan, suatu rumah tangga akan cenderung memiliki sepeda motor. Ini berarti bahwa mereka yang berpenghasilan tinggi akan lebih cenderung memiliki kendaraan lain daripada memiliki sepeda motor. Selain itu, Massara $d k k$. (2018) juga menyimpulkan bahwa masyarakat yang berpenghasilan rendah berpengaruh signifikan terhadap kepemilikan sepeda motor. Penelitian ini juga relevan dengan hasil penelitian yang dilakukan oleh Dargay $d k k$. (2007), Leong \& Sadullah (2007), Wedagama (2013) dan Oyedepo \& Etu (2015).
Peningkatan kepemilikan sepeda motor akan mengarah pada masalah transportasi yang serius di Kota Kupang untuk beberapa tahun ke depan. Hal ini berhubungan dengan dampak negatif dari transportasi termasuk kecelakaan lalulintas dan polusi yang ditimbulkan. Untuk mengatasi situasi ini, kepemilikan kendaraan suatu rumah tangga harus dibatasi dengan menggunakan kebijakan transportasi sebagai mekanisme harga melalui peningkatan terhadap biaya pengeluaran kendaraan dengan cara menaikkan pajak kendaraan, biaya bahan bakar dan ongkos parkir (Prabnasak $d k k$., 2011). Sebelum menerapkan kebijakan tersebut, layanan transportasi umum di Kota Kupang perlu ditingkatkan dengan memperbaiki kinerja pelayanannya sehingga bisa mempertahankan loyalitas pengguna transportasi umum (Semiun, 2018).

\section{Kesimpulan}

Model regresi multinomial logit kepemilikan sepeda motor dalam penelitian ini telah berhasil dikembangkan dan merupakan model MNL yang valid dan akurat. Berdasarkan kalibrasi hasil pemodelan, faktor yang berpengaruh signifikan terhadap kepemilikan sepeda motor di kota Kupang adalah jumlah anggota keluarga, penghasilan, jumlah anggota keluarga yang bekerja, jumlah anggota keluarga yang sekolah, dan waktu tempuh ke sekolah. Hasil analisis menunjukkan rumah tangga dengan jumlah anggota dua orang, penghasilan kurang dari dua juta rupiah, penghasilan dua sampai empat juta rupiah, jumlah anggota yang bekerja satu orang, jumlah anggota yang sekolah satu orang, dan waktu tempuh ke sekolah kurangg dari 15 menit dan 15 - 30 menit cenderung memiliki peluang yang lebih besar untuk memiliki satu sepeda motor daripada dua sepeda motor atau lebih. Perubahan ekstrim keseluruhan faktor yang mempengaruhi kepemilikan sepeda motor sebesar 50\% meningkatkan probabilitas kepemilikan satu sepeda motor sebesar $43.90 \%$, dua sepeda motor sebesar 42.07\% dan menurunkan probabilitas kepemilikan lebih dari dua sepeda motor sebesar $85.98 \%$ sebagai akibat dari kecenderungan untuk memiliki mobil pribadi. Pengembangan model ini telah memberikan indikasi pada tren yang diharapkan dari kepemilikan sepeda motor.

\section{Daftar Pustaka}

Aldrich, J. H. Nelson, F. D. (1984). Linear probability, logit and probit models. Newbury Park, CA: Sade publications.

Badan Pusat Statistik Kota Kupang. (2018). Kota Kupang dalam Angka. Kupang: BPS Kota Kupang. 


\section{TEKNIK, 40 (3), 2019, 194}

Dargay, J., Gately, D., Sommer, M. (2007). Vehicle Ownership and Income Growth, Worldwide: 1960-2030. The Energy Journal. 28(4), 143-170.

Gbagir, K., Etu, J. E., Oyedepo, O. J. (2018). Motorcycle Ownership Assessment and Estimation in Makurdi, North Central, Nigeria: A Multinomial Logit Model Approach. Journal of Civil Engineering, Science and Technology, 9(2), 87-97.

Hosmer, D. W., Lemeshow, S. (2000). Applied Logistic Regression (2nd ed.). New York: Wiley.

Leong, L. V., Sadullah, A. F. M. (2007). A Study on the Motorcycle Ownership : A Case Study in Penang State, Malaysia. Journal of the Eastern Asia Society for Transportation Studies, 7, 528-539.

Long, J. S. (1997). Regression Models for categorical and limited dependent variables. Thousand Oaks, CA: Sage.

Massara, A., Hakim, A., Wicaksono, A., Basri, L. (2018). Structural Equation Modeling On the Calculation of Motorcycle Ownership Index Using Amos Software. IOSR Journal of Business and Management (IOSR-JBM), 20(4), 35-43.

Oyedepo, O. J., Etu, J. (2015). Binomial logistic regression model of household motorcycle ownership in Akure, Ondo State, Nigeria. Journal of Transport Literature, 9(4), 40-44.

Prabnasak, J., Taylor, M.A.P., Yue, W.L. (2011) An Investigation of Vehicle Ownership and the Effect of Income and Vehicle Expenses in MidSized City of Thailand. Journal of the Eastern Asia Society for Transportation Studies, Vol. 9, 437-451.

Sanko, N., Dissanayake, D., Kurauchi, S., Maesoba, H., Yamamoto, T., Morikawa, T. (2014). Household car and motorcycle ownership in Bangkok and Kuala Lumpur in comparison with Nagoya. Transportmetrica A: Transport Science, 10(3), 187-213.

Semiun, O. E. (2018). Pengaruh Kualitas Pelayanan Angkutan Kota Terhadap Kepuasan dan Loyalitas Penumpang di Kota Kupang. Rekayasa Sipil, 12(1), 39-49.

Washington, S. P., Karlaftis, M. G., Mannering, F. L. (2003). Statistical and Econometric Methods for Transportation Data Analysis. USA : Chapman \& Hall.

Wedagama, D. M. (2013). The Influence of Income on Household Motorcycle Ownership in Buleleng Regency, Bali. Jurnal Ilmiah Teknik Sipil, 17(1), $18-25$. 